\title{
Taming Hegemony: Informal Institutions and the Challenge to Western Liberal Order
}

\author{
Jochen Prantl ${ }^{\dagger} *$
}

${ }^{\dagger}$ Associate Professor in International Relations in School of International, Political and Strategic Studies, Australian National University

*Corresponding author. Email: jochen.prantl@anu.edu.au.

\begin{abstract}
This article develops the argument that informal institutions-'G-x groupings', 'contact groups', 'core groups' - provide a vital space to renegotiate the terms and conditions of US hegemony. With the global balance of power shifting, US hegemony today is no longer seen as the exclusive framework to solve urgent collective action problems-major armed conflict, nuclear non-proliferation, climate change, global financial stability. These problems are of global significance and litmus tests for two key properties of US hegemonic power: the ability to maintain order and to provide public goods. As the global financial crisis of 2008 has demonstrated, emerging powers consider US hegemony as part of the problem rather than the framework through which to develop solutions. The substantial challenges for liberal institutions to adapt to major shifts in the global distribution of power and to act as effective problem-solvers has led to growing recourse to alternative mechanisms of collective action that operate in and around the liberal institutional architecture. However, they are not the convenient support structure for the renegotiation of Western liberal order on exclusive US terms. Informal institutions are platforms for contestation with an open outcome. Contestation includes the possibility of developing new patterns and understandings that may ultimately replace Western liberal order. The social contract between hegemonic leader and followers can be revoked. The contract will be up for termination if there is a widely shared belief that the hegemon fails to deliver sufficient public goods and proves to be incapable of performing its system maintenance functions.
\end{abstract}




\section{Introduction}

Hegemony-understood as patterns and understandings of special rights and responsibilities conferred on a state or a group of states with the resources to lead ${ }^{1}$-helped the United States after World War II to shape an unprecedented framework of international institutions and relationships that facilitated its sustained engagement in the resolution of global problems. ${ }^{2}$ Those institutions established rules and regulations that effectively preserved the core of the Western liberal order and cast the shadow of US hegemony well into the post-Cold War future. However, with the global balance of power shifting, US hegemony today is no longer seen as the exclusive framework to solve urgent collective action problemsmajor armed conflict, nuclear non-proliferation, climate change, financial stability. What these problems have in common is that they are of global significance. At the same time, they are litmus tests for the output legitimacy of hegemonic power, especially its two key properties, that is, the ability to maintain order and to provide public goods. Sustained failure of the hegemonic leader to perform these functions may erode the legitimacy of hegemonic order and result in termination of the social contract by the hegemonic followers. As the global financial crisis of 2008 has demonstrated, emerging powers consider US hegemony as part of the problem rather than the framework through which to develop solutions. ${ }^{3}$ The central puzzle this article seeks to address is therefore as follows: How to exercise hegemony in addressing urgent collection action problems when global order is in transition and U.S.-led liberal institutions have become contested?

\section{The Contestation of Liberal Order}

Western liberal order was essentially built around the United States and the industrialized Global North, which largely excluded the developing Global South. Rising wielders of power such as China and India are neither fully embedded in the system nor fully committed to the operating rules and principles of Western liberal order. Furthermore, the international response to conflict in Syria has highlighted the substantial constraints on US hegemony in mobilizing support for military intervention after chemical attacks by the Syrian government against opposition forces in 2013.

1 See lan Clark, Hegemony in International Society (Oxford: Oxford University Press, 2011); Mlada Bukovansky, Ian Clark, Robyn Eckersley, Richard Price, Christian Reus-Smit, and Nicholas Wheeler, Special Responsibilities: Global Problems and American Power (Cambridge: Cambridge University Press, 2012). The definition provides a useful bridge between rationalist and constructivist perspectives on hegemony.

2 This framework can indeed be described as a tributary system. See the excellent piece by Yuen Foong Khong, 'The American Tributary System', Chinese Journal of International Politics, Vol. 6, No. 1 (2013), pp. 1-47.

3 See Cornel Ban and Mark Blyth, 'The BRICs and the Washington Consensus: An Introduction', Review of International Political Economy, Vol. 20, No. 2 (2013), pp. 241-55. 
Confronted with major power shifts, the hegemon needs to address the challenge of recruiting enough followers to sustain its leadership. ${ }^{4}$ Primacy does not automatically translate into hegemony. It requires a legitimizing constituency that recognizes the status of the hegemon. One can express serious doubts as to whether the United States has enough authority to reform the institutional architecture of Western liberal order. ${ }^{5}$

At the same time, international organizations (IOs) are challenged by the increasing gap between their hugely increased geographical, functional, and normative ambitions and their lack of means to deliver them. On the one hand, the complexity of the post-Cold War economic and security environment seemed to generate the demand for a stronger architecture of Western liberal IOs in order to address collective action problems more effectively. The 1990s saw a plethora of proposals to reform the Bretton Woods institutions, World Trade Organization (WTO), and the United Nations (UN). ${ }^{6}$ On the other, the substantial challenges for Western liberal IOs to adapt to major shifts in the global distribution of power has led to growing recourse to alternative mechanisms of collective action-G-x groupings, contact groups, core groups-especially in times of crises. ${ }^{7}$

In the economic realm, the turn of the millennium suggested a renewed commitment to IOs, which was born out in the launch of the WTO's Doha Development Agenda. But the stalemate in the Doha negotiations and the recourse to smaller groups such as the G-6 involving the United States, European Union, Japan, Australia, Brazil, and India highlighted the deep tensions within the processes of formal multilateralism. In the financial realm, since 1999, the Group of Twenty Finance Ministers and Central Bank Governors (G-20) has sought to facilitate cooperation among systemically important developed and emerging economies in achieving financial stability in the wake of the East Asian financial crisis. ${ }^{8}$ Since 2008, the G-20 Leaders group has developed into the primary locus of global financial governance. In the security realm, especially in UN conflict resolution, there has been a proliferation of informal institutions working around the UN Security

4 See Barry Buzan, 'A Leader Without Followers? The United States in World Politics after Bush', International Politics, Vol. 45, No. 5 (2008), pp. 554-70.

5 See Christopher Layne, 'This Time It's Real: The End of Unipolarity and the Pax Americana', International Studies Quarterly, Vol. 56, No. 1 (2012), pp. 203-13.

6 See, for example, The Commission on Global Governance, Our Global Neighborhood (Oxford: Oxford University Press, 1995); Bretton Woods Commission, Report. Bretton Woods: Looking to the Future (Washington, DC: Bretton Woods Committee, 1994).

7 Adapting Mary Douglas' notion of cultural bricolage, these alternative mechanisms may be referred to as institutional bricolage, see James H. Mittleman, 'Global Bricolage: Emerging Market Powers and Polycentric Governance', Third World Quarterly, Vol. 34, No. 1 (2013), pp. 23-37.

8 The G-20 comprises Argentina, Australia, Brazil, Canada, China, France, Germany, India, Indonesia, Italy, Japan, Mexico, Russia, Saudi Arabia, South Africa, Republic of Korea, Turkey, United Kingdom, United States of America, and the European Union. 
Council. ${ }^{9}$ Between 1990 and 2006, one could observe 'a growth from four to more than thirty such mechanisms, a larger than sevenfold increase developed in parallel to the surge in conflict prevention, conflict management, and post-conflict peace building activities by the United Nations and others in the international community in this period'. ${ }^{10}$ The United States was directly involved in almost all of those groupings.

Neoliberal institutionalists such as John Ikenberry emphasize the role of Western liberal IOs and informal institutions in binding the hegemon through a framework of cooperation to reassure weaker states and to get their support in return. Such a constitutional bargain effectively locks-in a set of rules and institutions that will outlast change in the distribution of power. ${ }^{11}$ Ikenberry claims that the United States still possesses the material power to steer a transformation of global and regional order essentially on US terms and to achieve 'the reallocation of authority and leadership within the system'. ${ }^{12}$ In this context, informal institutions such as the G-20 appear as a kind of support structure to transcend liberal order. Analytically beguiling as it is, this claim seems to be based on ideological considerations rather than empirical analysis. It downplays the contested nature of liberal order that takes for granted a common belief-shared by the hegemonic leader and the weaker statesthat liberal institutions are and will remain the best place for striking a bargain.

Realists tend to emphasize the continued preponderance of US material capabilities, leaving US foreign policy with no constraints and unlimited options to remake the post-Cold War international order. ${ }^{13}$ Yet, hegemony is not the same as primacy. ${ }^{14}$ While material preponderance is a necessary, though not sufficient, condition, legitimacy is the sine qua non of hegemony. Legitimacy is defined here as 'a property of a rule or rule-making institution which itself exerts a pull towards compliance on those addressed normatively because those addressed believe that the

9 See Jochen Prantl, The UN Security Council and Informal Groups of States: Complementing or Competing for Governance? (Oxford: Oxford University Press, 2006).

10 Teresa Whitfield, Friends Indeed? The United Nations, Groups of Friends, and the Resolution of Conflict (Washington, DC: United States Institute of Peace Press, 2007), p. 4.

11 See G. John Ikenberry, After Victory: Institutions, Strategic Restraint and the Rebuilding of Order after Major War (Princeton: Princeton University Press, 2001); G. John Ikenberry, 'Multilateralism and U.S. Grand Strategy', in Stewart Patrick and Shepard Forman, eds., Multilateralism and U.S. Foreign Policy: Ambivalent Engagement (London: Lynne Rienner, 2002), pp. 121-40; G. John Ikenberry, 'Liberal Internationalism 3.0: America and the Dilemmas of Liberal World Order', Perspectives on Politics, Vol. 7, No. 1 (2009), pp. 71-87; G. John Ikenberry, Liberal Leviathan: The Origins, Crisis, and Transformation of the American World Order: The Rise, Decline and Renewal (Princeton: Princeton University Press, 2011).

12 Ikenberry, Liberal Leviathan, p. 9.

13 See Stephen G. Brooks and William C. Wohlforth, World Out of Balance: International Relations and the Challenge of American Primacy (Princeton: Princeton University Press, 2008).

14 See the useful account by Clark, Hegemony in International Society, pp. 18-28. 
rule or institution has come into being and operates in accordance with generally accepted principles of right process'. ${ }^{15}$ Material power does not automatically translate into hegemony. There needs to be a balance between coercion-based on material economic and military resources-and consent, which is not a given but subject to negotiation between hegemonic leader and followers. ${ }^{16}$ As a result, legitimacy is subject to successful negotiation of rules, norms, and principles underlying hegemony.

Analysis of hegemony therefore needs to account strongly both for the normative dimension of the concept, including the role of political and ideological leadership in creating consent. The demand for renegotiating the relationship between leader and followers is particularly high at times when the global balance of power is shifting order and hegemony is contested. As Andrew Hurrell stresses, it is 'the very clash of meanings, ideologies, and claims to justice, interacting with patterns of unequal power, which makes stable cooperation so problematic'. ${ }^{17}$

\section{The Argument}

This article develops the argument that informal institutions provide a vital space to contest and to renegotiate the terms and conditions of US hegemony. ${ }^{18}$ By informal institution is meant a cluster of connected norms, rules and principles, usually unwritten, around which actors' expectations converge in a given issue area. ${ }^{19}$ Those rules are negotiated, communicated, and enforced outside of formal IOs and regimes. Negotiation is understood here as 'a contest among partisans each attempting to establish the dominant subjective frame of reference'. ${ }^{20}$ Informal institutions

15 Thomas M. Franck, The Power of Legitimacy among Nations (Oxford: Oxford University Press, 1990), p. 24.

16 See Antonio Gramsci, Selections from the Prison Notebooks, edited and translated by Quintin Hoare and Geoffrey Nowell Smith (New York: International Publishers, 1971).

17 Andrew Hurrell, On Global Order: Power, Values, and the Constitution of International Society (Oxford: Oxford University Press, 2007), p. 39.

18 This argument departs from the observation that institutions are sites of unequal power, which emerging countries use for playing the game of institutionalized hierarchy. Andrew Hurrell, 'Hegemony, Liberalism and Global Order: What Space for Would-be Great Powers?', International Affairs, Vol. 82, No. 1 (2006), p. 10.

19 This definition borrows from Gretchen Helmke and Steven Levitsky, 'Informal Institutions and Comparative Politics: A Research Agenda', Perspectives on Politics, Vol. 2, No. 4 (2004), pp. 725-40; Hurrell, On Global Order, and Stephen D. Krasner, ed., International Regimes (Ithaca, NY: Cornell University Press, 1983). It serves the simple purpose of distinguishing the informal institutions under discussion from formal international (treaty-based) organizations and regimes.

20 John Odell, Negotiating Trade: Developing Countries in the WTO and NAFTA (Cambridge: Cambridge University Press, 2006), p. 19. 
are platforms for contestation of the dominant reference frame with an open outcome rather than a convenient support structure for the renegotiation of Western liberal order on exclusive US terms. Contestation includes the possibility of developing new patterns and understandings of order that may ultimately replace US hegemony.

Two ideal-type logics of informal institutions are explicated in this article, mediative and transformative, displaying two different negotiation strategies, integrative and distributive. ${ }^{21}$ The mediative logic refers to informal institutions as a political space for the contestation of ideas, ideologies, and interests. Looked at from the US perspective, they appear less constraining than formal IOs and thus more acceptable to a domestic audience, which perceives itself as 'exceptional'. ${ }^{22}$ Looked at from the perspective of weaker states, informal institutions may limit the hegemon's ability to impose its preferences on others, because the informal small-n setting provides participants with greater voice and influence in collective action outcomes compared to formal large-n IOs. ${ }^{23}$ Mediative informal institutions are characterized by integrative negotiation strategies of partisans that aim at exploring common solutions to the collective action problem at hand, yet without directly challenging the dominant reference frame. The transformative logic refers to a more long-term objective of emerging powers to remedy grievances through direct negotiations with the hegemon outside the constraints of formal IOs. Exiting from the framework of Western liberal institutions may lead to a new set of bargains on the underlying rules and principles of collective action. Transformative informal institutions feature distributive strategies of partisans that may produce an altered reference frame. In sum, informal institutions display a bargaining spectrum with integrative and distributive strategies at opposite ends. While the terminal point of the former is order maintenance, the terminal point of the latter is order transformation.

This article takes seriously the call of various scholars for greater eclecticism in studying International Relations by synergizing insights from different theoretical perspectives beyond methodological paradigms. ${ }^{24}$ Rationalist insights may help us to define better the boundaries and material conditions within which the

21 On the rise of emerging powers as a negotiated process, see Amrita Narlikar, 'Introduction: Negotiating the Rise of New Powers', International Affairs, Vol. 89, No. 3 (2013), pp. 561-76.

22 The point of US exceptionalism will be further elaborated below.

23 See, for example, Mancur Olson, The Logic of Collective Action: Public Goods and the Theory of Groups (Cambridge: Harvard University Press, 1965); Miles Kahler, 'Multilateralism with Small and Large Numbers', International Organization, Vol. 46, No. 3 (1992), pp. 681-708.

24 See J. Samuel Barkin, Realist Constructivism: Rethinking International Relations Theory (Cambridge: Cambridge University Press, 2010); Rudra Sil and Peter J. Katzenstein, 'Analytical Eclecticism in the Study of World Politics: Reconfiguring Problems and Mechanisms across Research Traditions', Perspectives on Politics, Vol. 8, No. 2 (2010), pp. 411-31. 
contestation of US hegemony takes place. ${ }^{25}$ As Keohane has observed, there are considerable material transaction costs to replace any architecture of hegemonic institutions with another one. ${ }^{26}$ This explains why we have not seen international efforts to redesign the post-World War II Western liberal architecture from scratch. Arguing in a similar vein, Snidal adds that material interests may in fact save declining hegemonic institutional arrangements, as long as the present arrangements can still deliver a critical mass of public goods for the less powerful. ${ }^{27}$ In addition, there is a burgeoning body of literature with several valuable insights on institutional choice or design. ${ }^{28}$ However, those accounts provide only a snapshot of the process of collective action and miss out a significant part of the description and explanation that are vital to explaining collective action outcomes. While recent comparisons of regional institutions produced useful accounts of why different forms of institutionalization exist in different parts of the world and whether variation in institutional design leads to variation in the nature of cooperation, ${ }^{29}$ such an approach has three limitations. First, the focus on institutional design generates a fairly static view on cooperation and obscures the shift of power that is currently occurring. Secondly, it obscures the dynamic processes of collective action problem-solving that often evolve simultaneously at the bilateral and multilateral levels. And thirdly, it fails to capture global-regional or cross-regional dynamics that are key for the understanding of cooperation.

Despite the importance of rationalists insights, material structures, power and interests cannot be understood without the underlying ideas, rules, and norms that

25 On standard rationalist accounts, emphasizing the material dimension of hegemonic power, see, for example, Stephen D. Krasner, 'State Power and the Structure of International Trade', World Politics, Vol. 28, No. 3 (1976), pp. 317-47; Robert Gilpin, War and Change in World Politics (Cambridge: Cambridge University Press, 1981); Robert O. Keohane, After Hegemony: Cooperation and Discord in the World Political Economy (Princeton: Princeton University Press, 1984); Duncan Snidal, 'The Limits of Hegemonic Stability Theory', International Organization, Vol. 39, No. 4 (1985), pp. 579-614; Charles P. Kindleberger, The World in Depression: 1929-1939 (Berkeley: University of California Press, 1986).

26 See Keohane, After Hegemony.

27 See Snidal, 'The Limits of Hegemonic Stability Theory'.

28 See, for example, Joseph Jupille, Walter Mattli, and Duncan Snidal, Institutional Choice and Global Commerce (Cambridge: Cambridge University Press, 2013); Felicity Vabulas and Duncan Snidal, ‘Organization without Delegation: Informal Intergovernmental Organizations (IIGOs) and the Spectrum of Intergovernmental Arrangements', Review of International Organizations, Vol. 8, No. 2 (2013), pp. 193-220; Randall W. Stone, Controlling Institutions: International Organizations and the Global Economy (Cambridge: Cambridge University Press, 2011); Barbara Koremenos, Charles Lipson, and Duncan Snidal, eds., The Rational Design of International Institutions (Cambridge: Cambridge University Press, 2004).

29 See Amitav Acharya and Alastair lain Johnston, eds., Crafting Cooperation: Regional International Institutions in Comparative Perspective (Cambridge: Cambridge University Press, 2007). 
can either be shared or contested. ${ }^{30}$ A constructivist perspective may help us to understand better the ideas, identity, and institutions that are shaping, taming, and potentially transforming US hegemony. For instance, much of the contestation over how to address collective action problems is triggered by US exceptionalism, that is, the self-perception of the United States to possess superior military and economic power which has shaped its identity in a way that makes it different from the rest. ${ }^{31}$ US exceptionalism is of critical importance in analysing cooperative or noncooperative behaviour in international institutions. The US self-assuredness of unconstrained power is deeply problematic for two reasons. First, it may invite contestation, if not resistance, by weaker states. And second, achieving legitimacy-in terms of compliance with United States preferred outcomes by weaker statesbecomes more difficult.

In substantiating my central argument, the remainder of this article is organized in three sections. The first section re-thinks the concept of binding institutions by introducing a new framework that helps to understand and explain the dynamics in the trilateral relationship between US hegemony, informal institutions, and Western liberal IOs. I then illustrate the framework by examining three critical cases at different historical junctures when central US security interests were at stake: (i) the dissolution of Yugoslavia, 1991-1995, which directly threatened NATO's credibility as a core Western liberal IO; (ii) the US-driven Proliferation Security Initiative (PSI) since 2003, attempting to close gaps in the nuclear non-proliferation regime; and (iii) the global financial crisis of 2008, which effectively ended the so-called Washington consensus on neoliberal rules and principles guiding global capitalism. The final section concludes with highlighting the findings of the article.

\section{Re-framing the Constitutional Bargain}

The starting point of the following section is that existing accounts of the constitutional bargain are too static. They tend to obscure crucial strategic developments

30 On accounts emphasizing the ideational dimension of hegemonic authority, particularly relying on Gramsci, see Robert Cox, 'Social Forces, States, and World Orders: Beyond International Relations Theory', Millennium, Vol. 10, No. 2 (1981), pp. 126-55. Most recently, Hopf provided a neo-Gramscian constructivist account of hegemony, aiming at bringing the role of common sense back into hegemonic theory. See Ted Hopf, 'Common-sense Constructivism and Hegemony in World Politics', International Organization, Vol. 67, No. 2 (2013), pp. 317-54.

31 See, for example, the recent opinion piece by the Russian President, Vladimir Putin, in the New York Times, in which he expressed strong concerns about a possible US military intervention in Syria. Putin warned against the notion of US exceptionalism, emphasizing that '[i]t is extremely dangerous to encourage people to see themselves as exceptional, whatever the motivation'. Vladimir V. Putin, 'A Plea for Caution from Russia', The New York Times, September 11, 2013. 
that reside in the negotiation of and contestation over US hegemony; ${ }^{32}$ they also tend to obscure variations in the expression of hegemony across regions. A more dynamic analytical framework is needed. Probing the relationship between US hegemony, informal institutions, and IOs helps to expose the changing character of the constitutional bargain. In developing this claim, this section, first, briefly reviews the main arguments of the binding institutions concept. Secondly, it explains why informal institutions proliferated in the post-Cold War order, followed by an investigation of why informal institutions are an attractive tool of US foreign policy. The section then outlines a new framework to study the dynamics between US hegemony and liberal institutions.

\section{The Concept of Binding Institutions}

The concept of binding institutions departs from the observation that the United States created Western liberal IOs in the aftermath of World War II to bind itself through a framework of cooperation in order to reassure weaker states and to get their support in return. ${ }^{33}$ The concept argues that, by complying with institutional norms and procedures, the United States entered into a constitutional bargain with the weaker states, generated by its interest to prevent the emergence of potential rivals or counter-coalitions; in return, weaker states benefit from hegemonic selfrestraint and US supplied global public goods which creates output legitimacy. At the same time, international institutions offer platforms for weaker states to articulate and pursue their interests within a relatively stable framework that creates procedural legitimacy. The bargain between hegemon and weaker states reduces the returns to power, thereby preventing disproportionate gains and limiting potential losses of the cooperating units. ${ }^{34}$ It is underlying a political order that comprises three essential features: first, there is a shared agreement on the basic rules and principles of the order; secondly, the exercise of power is constrained by and regulated through established rules and institutions; and thirdly, those rules and institutions cannot be easily changed without putting the constitutional bargain at stake. ${ }^{35}$ In a nutshell, the concept of binding institutions suggests a constitutional order that helps to lock-in a set of rules that will outlast change in the distribution of power.

32 Goh makes a similar point in relation to East Asia. See Evelyn Goh, The Struggle for Order: Hegemony, Resistance, and Transition in Post-Cold War East Asia (Oxford: Oxford University Press, 2013).

33 See G. John Ikenberry, 'Constitutional Politics in International Relations', European Journal of International Relations, Vol. 4, No. 2 (1998), pp. 147-77; G. John Ikenberry, 'Institutions, Strategic Restraint, and the Persistence of American Postwar Order', International Security, Vol. 23, No. 3 (1998-1999), pp. 43-78.

34 See lkenberry, After Victory, p. 32.

35 See Ikenberry, 'Constitutional Politics in International Relations', pp. 152-3. 
The logic of binding institutions has not remained uncontested. Schweller argued, for example, that 'the empirical record strongly suggests that international institutions have not checked the use of American power, which, in the most dramatic decisions since 1945, has been repeatedly exercised unilaterally - often without prior consultation with or even advance warning of its allies' ${ }^{36}$ Arguing in a similar vein, Walt observed that "using formal institutions to "bind" the United States is especially ineffective in areas where the U.S. advantage is especially pronounced - such as the use of military power - and where important security interests are at stake'. ${ }^{37}$

However, both proponents and opponents of 'binding institutions' miss out the key part of the description that captures the dynamic nature of the constitutional bargain. The bargain is not as fixed as Ikenberry seems to suggest. First, US hegemony is neither evenly distributed nor similarly expressed across regions. For example, while Europe has shown strong evidence of a constitutional bargain between the United States and regional institutions such as NATO, Central America and East Asia lack such evidence. Secondly, IOs and treaty-based regimes face substantial challenges in effectively addressing existential problems-e.g. armed conflict, nuclear non-proliferation, climate change, and the global governance of finance, which has led to global and regional cooperative arrangements that are often overlapping and-at times-competing. And thirdly, the underlying problems originating in the huge asymmetries of power in the post-Cold War global order have led to attempts to de-legitimize and soft-balance Western liberal power through new informal mechanisms such as the BRICS (Brazil, Russia, India, China, and South Africa) and non-liberal IOs such as the Shanghai Cooperation Organization (SCO), which essentially operates on a Sino-Russian condominium. ${ }^{38}$ Consequently, in order to better understand the changing character of US hegemony, the relationship between the Western liberal institutional architecture and informal institutions warrants greater scrutiny. ${ }^{39}$

\section{Why Informal Institutions?}

The proliferation of informal institutions in the post-Cold War order marks an important shift in the constitution of international society. Such institutions have come to play a range of critical roles and occupy a vital space between multilateral

36 Randall L. Schweller, 'The Problem of International Order Revisited', International Security, Vol. 26, No. 1 (2001), p. 164.

37 Stephen M. Walt, Taming American Power: The Global Response to U.S. Primacy (New York: W. W. Norton \& Company, 2005), p. 149.

38 On the role of the SCO in contesting Western liberal norms and principles, see Jochen Prantl, 'The Shanghai Cooperation Organization: Legitimacy through (Self-) Legitimation?', in Dominik Zaum, ed., Legitimating International Organizations (Oxford: Oxford University Press, 2013), pp. 162-78.

39 Recent academic work has thus far only focused on the importance of informal rules within IOs. See Stone, Controlling Institutions. 
governance on the one hand and traditional major power diplomacy on the other. The proliferation of informal institutions has been triggered by the triple effects of globalization (economic, environmental, security, social, and cultural), breakdown of the bi-polar system, and rising powers, which have challenged the problem-solving capacities of formal multilateral frameworks. In order to uncover those challenges, one needs to look at two levels of analysis, systemic and organizational. At the systemic level, English-School Theory helps in explaining the underlying tensions between multilateral diplomacy and the management of unequal power. On the one hand, one can observe a push towards solidarism, which is epitomized in the expanding geographical, functional, and normative scope of international society. On the other hand, the pull of pluralism is persisting, because the asymmetries of power between the units of the international system are considerable, and the effects of globalization on states and institutions are not equally distributed on a global scale. ${ }^{40}$ At the institutional level, major shifts in the global distribution of power and production have further exposed the structural constraints of IOs and treaty-based regimes and reduced their capacity to solve problems. In a nutshell, IOs and regimes have become challenged by the gap between highly increased geographical, functional, and normative ambitions and the lack of means to deliver them. Informal institutions may provide platforms to escape what one may call 'the multilateral predicament'.

Analysis of informal institutions highlights that there is more variation in the function of international institutions than normally acknowledged. Rather than studying informal institutions and IOs in binary terms, multilateral governance is best understood as interrelated processes and institutions that are located on a formal-informal continuum, with varying degrees of formalization and legalization across regions. At the thinner end of the spectrum, we may find unspoken rules, tacit understandings, coordination, and bargaining. ${ }^{41}$ Somewhere in the middle, we may see functional or issue-specific groupings-G-x groups, coalitions of the willing, contact groups, core groups, and groups of friends. Those informal institutions usually form around specific issues and develop a set of procedural norms-mostly unwritten-governing, inter alia, membership, operational practices, and decision rules, acting either inside the formal organization, or within the objectives of a resolution or a mandate of an established IO but outside its formal structures, or they can exist wholly outside of that framework. At the thicker end of the formal-informal spectrum, we may find IOs that nevertheless in themselves display significant differences in their pattern of legalization and formalization across regions. ${ }^{42}$

40 See Hurrell, On Global Order.

41 See Thomas C. Schelling, The Strategy of Conflict (Cambridge, MA: Harvard University Press, 1960); Paul Keal, Unspoken Rules and Superpower Dominance (London and Basingstoke: Macmillan, 1983).

42 A narrow analytical focus on institutional design and effectiveness ultimately conceals rather than reveals the dynamics of collective action evolving on the formal-informal continuum. 
Informal groups are of particular importance in times of major power shifts. The hegemonic leader-follower relationship can only be insufficiently accommodated within IOs and treaty-based regimes, because they reflect and tend to freeze the distribution of relative power at the time of their creation. Informal groups provide flexible avenues for reviewing, contesting, and adjusting the terms and conditions of the hegemonic contract, which is differently expressed across regions and issue areas. $^{43}$

\section{US Exceptionalism and the Demands of Legitimacy}

Looked at from the perspective of US foreign policy, much of the attractiveness of informal institutions originates in the exceptionalist power of the United States. The notion of US exceptionalism, coined over one and a half decades ago by Alexis de Tocqueville, raises the still very relevant question of the extent to which the United States is in important respects distinctly different from other countries:

I consider the people of the United States as that portion of the English people who are commissioned to explore the forests of the New World, while the rest of the nation, enjoying more leisure and less harassed by the drudgery of life, may devote their energies to thought and enlarge in all directions the empire of mind. The position of the Americans is therefore quite exceptional, and it may be believed that no democratic people will ever be placed in a similar one. ${ }^{44}$

While the United States may no longer explore the forests of the New World, it still possesses exceptional material resources feeding its self-perception of being different from the rest. For much of US history, this argument has been used to justify isolationism. At the same time, US exceptionalism translates into a foreign policy that tends to seek maximum flexibility and unrestricted freedom in the exercise of power. However, a foreign policy that is grounded in the self-perception and self-assuredness of unconstrained power is deeply problematic, especially at times of major power

43 Obviously, informal institutions do not always trigger a change in the hegemonic status quo. Yet, there are platforms for contestation with an open outcome. And indeed, this implies that informal groups may also be instrumental in preserving the status quo, as it is evident, for example, in the area of climate change. I am indebted to one of the Reviewers to highlight this point.

44 Alexis de Tocqueville, Democracy in America, Vol. 2 (New York: Alfred Knopf, 1945), pp. 39-40. For more recent thoughts on American exceptionalism, see Seymour Martin Lipset, American Exceptionalism: A Double-Edged Sword (New York: W. W. Norton, 1996); Byron E. Shafer, ed., Is America Different? A New Look at American Exceptionalism (Oxford: Clarendon Press, 1991); William M. Reisman, 'The United States and International Institutions', Survival, Vol. 41, No. 4 (1999-2000), pp. 62-80; Robert Kagan, Of Paradise and Power: America and Europe in the New World Order (New York: Vintage Books, 2004); Michael Ignatieff, ed., American Exceptionalism and Human Rights (Princeton: Princeton University Press, 2005); Francis Fukuyama, America at the Crossroads: Democracy, Power, and the Neoconservative Legacy (New Haven: Yale University Press, 2006). 
shifts. First, it may effectively undermine the legitimacy of power-based outcomes. As Inis Claude observed almost five decades ago, 'power and legitimacy are not antithetical, but complementary'. ${ }^{45}$ Secondly, it may invite resistance by 'the weak', leading to the building of counter-coalitions to limit the room-for-maneuver of 'the strong'. Those two challenges will be further elaborated in the remainder of this sub-section.

Legitimate foreign policies are the result of a complex two-level game in which leaders communicate with their respective audiences at a domestic and an international table. ${ }^{46}$ At the domestic table, US exceptionalism generates a distinct understanding of legitimacy, which is especially pronounced in relation to the use of force. A cursory look at interventions in Grenada (1983), Panama (1989), Iraq-Kuwait (1991), Haiti (1994), Kosovo (1999), and Iraq (2003) illustrates that concerns over risks, costs, and effectiveness of the operation clearly outweighed considerations related to international legitimacy. While the blessing of the UN is desirable, US policymakers do not consider this the sine qua non for using force. Process is clearly subordinate to results. At the international table, US exceptionalism creates a very strong demand for complicity and compliance by 'the rest', which cannot be taken for granted. The US intervention in Iraq may serve as a strong reminder of how the lack of international legitimation can in fact compromise the effectiveness of an operation. Moreover, the failure of the September 2013 G-20 summit in Russia to produce international agreement on military action in Syria in response to President Bashar alAssad's chemical weapon attacks is a compelling example of how the followership of US hegemony has declined since 2003. ${ }^{47}$ Unconstrained power raises concerns about legitimacy by friends and foes alike. The rise of the rest makes it even more difficult for the United States to perform the function of privilege taker and system maker. The US ability to deliver and to sell public goods has eroded.

In sum, the rule systems for legitimation at the national and international tables are interdependent. ${ }^{48}$ US exceptionalism is heavily dependent on a critical mass of international followers, including an institutional support structure, sanctioning its claimed privileges. Informal institutions may provide alternative mechanisms to address the tensions between the two tables, allowing US foreign policy to escape the multilateral predicament while securing an aura of international legitimacy.

45 Inis Claude, 'Collective Legitimization as a Political Function of the United Nations', International Organization, Vol. 20, No. 3 (1966), p. 368.

46 Robert D. Putnam, 'Diplomacy and Domestic Politics: The Logic of Two-Level Games', International Organization, Vol. 42, No. 3 (1988), pp. 427-60.

47 See United Nations, Final Report of the United Nations Mission to Investigate Allegations of the Use of Chemical Weapons in the Syrian Arab Republic, S/2013/735, December 13, 2013.

48 Harold James, The Roman Predicament: How the Rules of International Order Create the Politics of Empire (Princeton: Princeton University Press, 2006), p. 2. 


\section{US Hegemony and the Liberal Institutional Architecture}

Having addressed the question of why informal institutions proliferated in the postCold War era and why they provide attractive mechanisms for the legitimation of US foreign policy with fewer strings attached, this sub-section re-frames the dynamics between US hegemony and liberal institutions.

Underlying any political order is at least some form of hierarchy that defines how societies are organized. E.H. Carr observed long ago that

any international moral order must rest on some hegemony of power. But this hegemony, like the supremacy of a ruling class within the state, is in itself a challenge to those who do not share it; and it must, if it is to survive, contain an element of give-and-take, of self-sacrifice on the part of those who have, which will render it tolerable to the other members of the world community. ${ }^{49}$

Two important insights flow from there. First, hegemony is a defining feature of order, which conditions the institutional design and workings of IOs and treatybased regimes. Secondly, analysis of hegemony needs to go beyond a too-narrow focus on relative power and capabilities. Rather than describing an essentially static situation of power concentration where one country possesses more material resources than another, hegemonic power involves a dynamic two-way relationship between a leader and a group of followers. Hegemony involves a social relation in which status is conferred upon a powerful country by weaker states. This implies that the special rights and responsibilities - both status markers of hegemonic leadership-are contingent. They can be contested and ultimately revoked. In this context, contestation means a spectrum of possible actions that may take the form of either resisting-e.g. through hard or soft balancing ${ }^{50}$ —or renegotiating the terms and conditions of hegemony.

Both resistance and renegotiation require further qualification. Resistance immediately raises the question of the extent to which weaker states have the capabilities to directly challenge the US hegemony. The post-Cold War era has been in fact characterized by an absence of serious attempts to form formal alliances against the United States. ${ }^{51}$ While hard balancing seems to be a less prudent strategy, instead

49 E. H. Carr, The Twenty Years' Crisis, 1919-1939: An Introduction to the Study of International Relations (London: Macmillan, 1962), p. 168.

50 Soft balancing is obviously not the only alternative to hard balancing. For a good review of other strategies available to respond to hegemony, see Thomas J. Christensen, 'Posing Problems without Catching Up: China's Rise and Challenges for U.S. Security Policy', International Security, Vol. 25, No. 4 (2001), pp. 5-40.

51 See Michael Mastanduno, 'Preserving the Unipolar Moment: Realist Theories and U.S. Grand Strategy after the Cold War', International Security, Vol. 21, No. 4 (1997), pp. 49-88; Charles A. Kupchan, 'After Pax Americana: Benign Power, Regional Integration, and the Sources of a Stable Multipolarity', International Security, Vol. 23, No. 2 (1998), pp. 40-79; William C. Wohlforth, 'The Stability of a Unipolar World', International Security, Vol. 24, No. 1 (1999), pp. 5-41; Brooks and Wohlforth, World Out of Balance. 
one can observe softer and subtler non-military approaches, which have been different from the traditional military balancing. Soft balancing has become an alternative policy option. ${ }^{52}$ It is understood as the 'conscious coordination of diplomatic action in order to obtain outcomes contrary to U.S. preferences - outcomes that could not be gained if the balancers did not give each other some degree of mutual support'. ${ }^{53}$ Renegotiating the terms and conditions of hegemony may take form of, at one end of the continuum, legally binding written agreements, and, at the other end, selfimposed restraints. ${ }^{54}$ In between, one may find non-binding written agreements, spoken and unspoken rules and tacit understandings. ${ }^{55}$

While the combination of formal and informal rules within IOs and treaty-based regimes allows for some discretion in calibrating the constitutional bargain between hegemonic leader and followers, existential problems arise if power is shifting and order itself becomes subject to change. On the one hand, hegemony may become defunct, if the divergence between power structure and social order is becoming too stark. ${ }^{56}$ On the other hand, IOs and treaty-based regimes themselves face considerable structural constraints to formally adapt to major power shifts. Without adaptation and change, they lose their capability to act as effective problem-solvers.

In order to understand better the complex relationship between US hegemony and Western liberal institutions, further disaggregation of the functions and roles of informal institutions is necessary. One can distinguish between two Weberian idealtypes of informal institutions-exit and voice. ${ }^{57}$ Both types are 'outside options' acting in and around the formal institutional architecture of Western liberal order. ${ }^{58}$ Exit institutions are created in response to a perceived decrease in the performance or benefit of an IO or treaty-based regime to a member state or a group of member states. With the Western liberal IOs under challenge, exit institutions provide

52 See Robert A. Pape, 'Soft Balancing against the United States', International Security, Vol. 30, No. 1 (2005), pp. 7-45; T. V. Paul, 'Soft Balancing in the Age of U.S. Primacy', International Security, Vol. 30, No. 1 (2005), pp. 46-71; Stephen M. Walt, 'Keeping the World "Off-Balance": Self-Restraint and U.S. Foreign Policy', in G. John Ikenberry, ed., America Unrivaled: the Future of the Balance of Power (Ithaca: Cornell University Press, 2002), pp. 121-54.

53 Walt, 'Keeping the World "Off-Balance"', p. 126.

54 See Raymond Cohen, 'Rules of the Game in International Politics', International Studies Quarterly, Vol. 24, No. 1 (1980), pp. 129-50.

55 See Keal, Unspoken Rules and Superpower Dominance.

56 See Barry Buzan, The United States and the Great Powers: World Politics in the TwentyFirst Century (Cambridge: Polity, 2004), p. 148.

57 See Albert 0. Hirschman, Exit, Voice, and Loyalty: Responses to Decline in Firms, Organizations, and States (Cambridge: Harvard University Press, 1970). This section extends the argument developed in Jochen Prantl, 'Informal Groups of States and the UN Security Council,' International Organization, Vol. 59, No. 3 (2005), pp. 559-92.

58 Phillip Lipscy, Explaining Institutional Change: Policy Areas, Outside Options and the Bretton Woods Institutions. Unpublished paper, http://stanford.edu/ plipscy/ paperIMFWBoutsideoptions.pdf. 
dissatisfied states with an option to remedy grievances through direct negotiations with the hegemon in an informal small-n setting. In a nutshell, exiting from liberal IOs allows partisans to pursue distributive strategies that may lead to an altered reference frame with a new set of bargains on the underlying rules and principles of collective action. Exit, in its most extreme form, goes beyond the mere renegotiation of liberal IOs. The ultimate logic of exit institutions is transformative. It implies a more long-term objective by the partisans with an endgame in mind. Order transformation is the terminal point.

Voice institutions provide partisans with a forum to improve or repair the loss of quality of an IO or regime through enhanced negotiation and communication. Stakeholders not being represented on the central decision-making bodies of an IO or regime may articulate their interests (or dissatisfaction) and may informally influence agenda-setting and/or decision-making. The ultimate logic of voice institutions is mediative. They provide a political space for the contestation of ideas, ideologies, and interests, yet within the confines of Western liberal order. Mediative informal institutions are characterized by integrative negotiation strategies that seek agreement on how to cooperate and renegotiate IOs without directly challenging the dominant reference frame. Order maintenance is the terminal point.

Exit and voice institutions perform upward and downward functions. Upward, informal institutions provide a vital space to renegotiate those bargains that define the sets of relationships among major powers and weaker states. Downward, they translate the substance of the renegotiated bargain into the institutional process of IOs. This will be further illustrated in the empirical section below. Following from the above, informal institutions may in fact display four ideal-type effects on IOs or treaty-based regimes: accommodation; complementation; competition; and substitution (Figure 1): ${ }^{59}$

1. Accommodating informal institutions create voice opportunities for stakeholders not represented within an $\mathrm{IO}$ or a regime.

2. Complementary informal institutions fill gaps in the institutional machinery of IOs or regimes.

3. Competing informal institutions co-exist with ineffective IOs or regimes by escaping their structural inefficiencies, having a low degree of convergence with formal rules and procedures.

4. Substitutive informal institutions replace IOs or regimes by creating their own rules and procedures to ensure effective collective action problem-solving.

So far, both exit and voice institutions have operated within the confines of the US-led Western liberal order. They have taken on roles in reforming and

59 Insights from recent work in comparative government are helpful here. See Hans-Joachim Lauth, 'Informal Institutions and Democracy', Democratization, Vol. 7, No. 4 (2000), pp. 21-50; Helmke and Levitsky, 'Informal Institutions and Comparative Politics'. 


\begin{tabular}{|c|c|c|c|}
\hline $\begin{array}{c}\text { Type of informal } \\
\text { institution }\end{array}$ & $\begin{array}{c}\text { Logic of informal } \\
\text { institution }\end{array}$ & $\begin{array}{c}\text { Negotiation } \\
\text { strategy }\end{array}$ & Effects on IOs \\
\hline & Mediative & Integrative & Accommodating \\
& & & \\
Exit & Transformative & Distributive & \begin{tabular}{c} 
Substitutive \\
\hline
\end{tabular} \\
\hline
\end{tabular}

Fig. 1 Informal Institutions and IOs.

renegotiating rather than resisting and revolutionizing the global order. The push of exit and voice institutions is essentially contained by a loyalty pull that originates in the belief of both US followers and potential contenders that the hegemonic liberal order-despite its shortcomings-still provides enough public goods. Belief in this context goes well beyond the rationalist argument of continued material interests that may uphold the institutional architecture of hegemonic order. ${ }^{60}$ Despite the ongoing contestation of the ideas, rules, and norms underlying US hegemony, there still is enough pull towards compliance on the hegemonic followers. It is output legitimacy that keeps Western liberal order intact. In order to change the status quo, a normative shift is needed to trigger revolution rather than reform of global order. While the world financial crisis of 2008 illustrated the crisis of Western capitalism, it has not yet produced a shift in global norms that would transform Western liberal order.

As this section has demonstrated, informal institutions are by no means the convenient support structure for the renegotiation of Western liberal order on US terms. Exit and voice institutions are platforms for contestation with an open outcome. Contestation includes the possibility of developing new patterns and understandings that may ultimately replace Western liberal order. The social contract between hegemonic leader and followers can be revoked. In a nutshell, the contract will be up for termination if there is a widely shared belief that the hegemon fails to deliver sufficient public goods and proves to be incapable of performing its system maintenance functions. In sum, working through informal institutions may therefore reduce the risk of hegemonic instability, as they provide regular procedures for interaction to address concerns about the legitimacy of US foreign policy and ameliorate the 
security dilemma between participating states. ${ }^{61}$ These regular procedures may ultimately transform single into collective hegemony, ${ }^{62}$ allowing for checks and balances within a concert of powers. If executed well, the confidence of the dissatisfied could be won and 'peaceful change' could result. ${ }^{63}$

\section{US Hegemony and Informal Institutions: Escaping the Multilateral Predicament}

This section illustrates the analytical framework by examining three critical cases at different historical post-Cold War junctures when central US security interests were at stake. These cases were of global significance and litmus tests for the output legitimacy of US hegemonic power. The case selection takes seriously the earlier mentioned criticism that the 'binding institution' argument is particularly weak in areas where US security interests are strong and its preponderance is overwhelming. ${ }^{64}$

The first case investigates the role of the Contact Group in addressing conflict in former Yugoslavia (1991-1995). While the dissolution of the Yugoslav territory itself did not constitute a short-term vital security threat to the United States, the failure of core Western liberal institutions-European Community/Union, NATO, $\mathrm{UN}$ - to deal effectively with the conflict along with the extremely volatile situation in Russia-a key stakeholder in the resolution of the conflict-put central long-term US security interests in Europe at risk. The second case, PSI (since 2003), constitutes an important post-Cold War challenge of the United States to achieve one of the long-standing key objectives in its national security strategy, that is, preventing the spread of nuclear weapons and securing nuclear materials. ${ }^{65}$ The third case investigates the role of the G-20 in addressing the global financial crisis of 2008, which highlighted the weakness of the United States and the established G-7 while sharply underlining the growing importance of emerging powers, most notably China. ${ }^{66}$

61 See Glenn H. Snyder, 'The Security Dilemma in Alliance Politics', World Politics, Vol. 36, No. 4 (1984), pp. 461-95.

62 See J. H. Adam Watson, Hegemony and History (London: Routledge, 2007); Clark, Hegemony in International Society. Although the concept of collective hegemony is contested, it is worth mentioning here. The Concert of Europe, the five permanent members of the UN Security Council, and the various $\mathrm{G}-\mathrm{x}$ groupings may serve as examples of collective hegemony.

63 Carr, The Twenty Years' Crisis, 1919-1939, p. 222. See also Barry Buzan and Michael Cox, 'China and the US: Comparable Cases of "Peaceful Rise"?', Chinese Journal of International Politics, Vol. 6, No. 2 (2013), pp. 109-32.

64 See Walt, Taming American Power.

65 See Graham T. Allison, Owen R. Coté, Richard A. Falkenrath, and Steven Miller, Avoiding Nuclear Anarchy. Containing the Threat of Loose Russian Nuclear Weapons and Fissile Material (Cambridge: MIT Press, 1996).

66 The G-7 consists of the finance ministers of the following countries: Canada, France, Germany, Italy, Japan, United Kingdom, and United States. 
The three cases together provide enough geographical, issue, and temporal variance to study critical changes in the terms and conditions of US hegemony in the post-Cold War period.

\section{Contact Group and the Dissolution of Yugoslavia (1991-1995)}

The end of the Cold War in Europe seemed to suggest rejuvenation of the Western liberal project and with it US hegemony. The transformation of Europe brought German unification, which was celebrated as a triumph of US-led bi- and multilateral diplomacy. ${ }^{67}$ It also brought reinforcement of the liberal institutional architecture, because Europe's transformation was firmly embedded in the framework of European integration, the NATO military alliance, and the Conference on Security and Cooperation in Europe (CSCE). ${ }^{68}$ The early 1990s were marked by collective Western attempts to incorporate the former Communist East by extending the patterns and understandings of the liberal project. This extension of the Western liberal project worked reasonably well for the Central and Eastern European small and middle-powers, which aspired for membership in the European Community and NATO. The constitutional bargain underlying the US-led Western liberal order remained, by and large, unchanged.

However, there were clear limits in extending the same logic to Russia, which expressed little willingness to join the Western liberal project solely on US terms. PostCold War euphoria in Europe over-emphasized the potential for comprehensive and cooperative security while under-exposing the perils and pitfalls of an alienated Russia that was weakened but still nuclearized. The dissolution of Yugoslavia clearly exposed the substantial challenges of post-Cold Wara liberal institutions to solve existential problems such as armed conflict. It also highlighted the need to negotiate a new bargain that would accommodate Russian interests and redefine responsibilities of the United States and its European allies in providing peace and security in post-Cold War Europe.

Conflict in Yugoslavia was triggered by economic decline and constitutional crisis in the 1980s that had destabilized the fragile Yugoslav entity. The end of the Cold War fostered secessionist tendencies in the federation: Croatia and Slovenia declared their independence on June 25, 1991, followed by Bosnia and Herzegovina on April 6, 1992. ${ }^{69}$ The escalating tensions and violence in Bosnia turned into fullfledged war, which lasted three and a half years until October 1995. Peace

67 See Philip Zelikow and Condoleezza Rice, Germany Unified and Europe Transformed: A Study in Statecraft (Cambridge: Harvard University Press, 1995).

68 See Robert 0. Keohane, Joseph Nye, and Stanley Hoffmann, eds., After the Cold War: International Institutions and State Strategies in Europe, 1989-1991 (Cambridge: Harvard University Press, 1993).

69 See Susan L. Woodward, Balkan Tragedy: Chaos and Dissolution after the Cold War (Washington, DC: Brookings Institution, 1995), pp. 47-81. 
negotiations culminated on 21 November in the Dayton Accords, signed in Paris on December 14, 1995 and endorsed by UN Security Council resolution 1031 the following day. ${ }^{70}$

\section{The Predicament of Western Liberal Security Institutions}

The most striking feature of the international response to the break-up of Yugoslavia was the incrementalist and piecemeal approach of key players, which illustrated that neither was there agreement on the causes of the conflict nor on the means on how to address it. When the crisis in Yugoslavia unfolded, European security institutions - in particular the European Community (EC), the CSCE, and NATO — had been amidst a process of major transformations. At UN headquarters, the response to the dissolution of Yugoslavia was driven by attempts to contain rather than to solve the conflict. In September 1991, the Security Council imposed an arms embargo on the Yugoslav territory, which effectively disadvantaged Bosnian Muslim forces, since Serbia had inherited the bulk of the former Yugoslav People Army's military equipment. Five months later, Council members agreed to deploy a lightly armed peacekeeping force (UNPROFOR)—with France and the United Kingdom as the largest troop contributors-to create conditions on the ground that would allow for the negotiation of an overall settlement of the Yugoslav crisis.

However, as the war unfolded, there was a strong disagreement between the United States and major European powers over the extent to which international diplomacy should be backed by the use of force. When the US administration suggested in May 1993 to lift the UN arms embargo in order to supply Bosnian Muslims with weapons along with the threat of air strikes against Bosnian Serbs, the proposal was rejected by France, Germany, United Kingdom, and Russia. ${ }^{71}$

Unlike in the Persian Gulf, the United States initially considered the Yugoslav conflict a regional dispute that should be primarily dealt with by the Europeans. In the summer of 1991, there was a clear understanding in Washington that 'Serbia didn't have Iraq's capability or ability to affect America's vital interests, such as access to energy supplies'. ${ }^{72}$ Furthermore, the increasingly volatile situation in the Soviet Unionleading to its demise in December 1991—-posed a far greater threat to US interests. The Soviet nuclear arsenal was a matter of particular concern, given the potential ramifications for global security. Stabilizing the Russian Federation and addressing the security vacuum in Eastern Europe were on top of the US foreign policy agenda. ${ }^{73}$

70 See Ivo H. Daalder, Getting to Dayton: The Making of America's Bosnia Policy (Washington, DC: Brookings Institutions Press, 2000).

71 Andrew J. Bacevich, American Empire: The Realities and Consequences of U.S. Diplomacy (Cambridge: Harvard University Press, 2002), p. 92.

72 James A. Baker, III, The Politics of Diplomacy: Revolution, War and Peace, 1989-1992 (New York: G.P. Putnam's Sons, 1995).

73 See Strobe Talbott, The Russia Hand: A Memoir of Presidential Diplomacy (New York: Random House, 2002). 


\section{Contact Group: Exit Mechanism for Stakeholders (1994-1995)}

The Contact Group on former Yugoslavia-comprising France, Germany, Russia, United Kingdom, and the United States—established 'an informal but strong policymaking core around which the main international players could unite'. ${ }^{74}$ The group emerged in April 1994 by default rather than by design and provided an exit mechanism for major powers to cooperate outside the constraints of the CSCE, EC/EU, and the UN, which had failed thus far to settle the conflict. At the same time, the Contact Group was particularly important 'to keep Russia... inside the tent... sullen but not obstructionist'. ${ }^{75}$ Recognizing Russia's continued status as major power proved to be of vital importance, because it helped to keep Moscow's significant obstructionist potential under control. ${ }^{76}$

US participation in the Contact Group reflected initially a semi-institutionalized commitment to its European allies yet without becoming fully engaged in managing the conflict. However, the pressure on the Clinton Administration to review its Bosnia policy increased dramatically when UN peacekeepers were taken hostage, UNPROFOR was at the brink of collapse, and NATO's viability and credibility as security provider was at stake. ${ }^{77}$ The crisis of confidence peaked after the massacre of Srebrenica in July 1995, when more than 8000 Bosnian Muslims were killed by Bosnian Serb forces. Deeply concerned about the lack of effective Western response, 'some Czechs, Hungarians and Poles began expressing second thoughts about whether they should even want to be in a Western alliance that had shown itself to be so easily cowed'. ${ }^{78}$ By summer 1995 , it was clear that the United States needed to become more engaged in former Yugoslavia, because the conflict now endangered the accomplishment of US vital security interests: the stabilization of Russia, peace and stability in Eastern Europe, and the credibility of NATO as an effective postCold War security alliance.

\section{Transforming the Terms of US Hegemony in Post-Cold War Europe}

The Contact Group helped to forge a new bargain on security order in Europe that changed the terms of US hegemony by accommodating Russian interests and redefining responsibilities of the United States and its European allies. Its primary logic was therefore transformative. While the diversity of Contact Group membership limited the operational role of the mechanism, nevertheless, it was able to agree

74 Pauline Neville-Jones, 'Dayton, IFOR and Alliance Relations in Bosnia', Survival, Vol. 38, No. 4 (1996), p. 46.

75 Talbott, The Russia Hand, p. 123.

76 For example, after NATO had issued an ultimatum to the Serbs in February 1994, Russian President Yeltsin implied in a phone conversation with US President Clinton that a military attack by the Western Alliance may trigger a nuclear response by the Russian Federation. See Talbott, The Russia Hand, p. 122.

77 See Daalder, Getting to Dayton.

78 Talbott, The Russia Hand, p. 170. 
upon the basis for a negotiated settlement of the war in Bosnia-Herzegovina. ${ }^{79}$ Looked at from the perspective of US foreign policy, the Contact Group reflected a trade-off between the interest of having maximum flexibility in the conduct of crisis management and the dependency on the support of key players. However, this was a deeply contested process full of tensions. Richard Holbrooke specified those tensions in a personal note to then US Secretary of State Warren Christopher in August 1995:

The Contact Group presents us with a constant conundrum. We can't live without it, we can't live with it. If we don't meet with them and tell them what we are doing, they complain publicly. If we tell them, they disagree and often leak - and worse. In the end, we must keep the Contact Group together, especially since we will need it later to endorse and legitimize any agreement. ${ }^{80}$

In order to secure essential support from major allies-France, Germany, and the United Kingdom-and to prevent obstructionist policies from Russia, the United States had to accept a bargain that resulted in a reduction of policy autonomy and a limited ability to exercise unconstrained power. While the United States exercised strong leadership between summer and autumn 1995 to end the war in Bosnia, no peace agreement would have been possible without renegotiating the terms of US hegemony. Three key features of the new bargain that emerged from the Contact Group process stand out:

1. Russian inclusion but not subordination constituted the cornerstone of the new bargain underlying European security order. Russia's participation in the NATO-led Bosnia Implementation Force to implement the provisions of the Dayton Accords signaled the end of NATO's Cold-War rationale, as famously described by its first Secretary-General, Lord Ismay: to keep the Russians out, the Americans in, and the Germans down.

2. The bargain also highlighted a new task-sharing between the United States and Europe. While military security would depend to a large degree on US assets and leadership (provided through NATO), the civilian aspects of implementing the Dayton Accords, including the responsibility of forming an International Police Task Force (IPTF), was placed under European leadership. At the same time, the United States yielded to strong European preferences to place IPTF under UN control.

3. Ancillary to the two previous points, the Contact Group effectively transformed US hegemony into collective hegemony, shared especially between the United

79 The Contact Group Plan, presented in July 1994, allocated $49 \%$ of the territory to the Bosnian Serb side and $51 \%$ to the Croat-Muslim Federation. However, at this stage, the Plan did not reflect the military balance of power on the ground, as Bosnian Serbs held roughly $72 \%$ of the territory. The Contact Group neither presented a comprehensive strategy nor provided the necessary means to enforce the partition; see Daalder, Getting to Dayton, pp. 94-95.

80 Richard Holbrooke, To End a War (New York: The Modern Library, 1999), p. 84. 
States and Russia, which allowed for checks and balances within a minilateral framework. To give one example, the Dayton agreement would not have been possible without the lifting of UN sanctions on Serbia, especially the resumption of gas supplies to Belgrade, which Serbian President Slobodan Milosevic had strongly demanded. Only Russia, as the main European gas supplier, was in the position to meet those demands. As a result, the success of the Dayton peace conference was contingent on Russian support.

In conclusion, the Contact Group on former Yugoslavia emerged as an exit institution that transformed single into collective hegemony, shared between the United States, Russia, and major European powers. The mechanism imposed checks and balances on US hegemony. In effect, Contact Group policies were the result of successful great power management and compromise, which decreased the likelihood of obstruction or defection by major powers. The logic of the Contact Group was transformative, as it allowed for negotiation of a new set of post-Cold War bargains in maintaining security order in Europe, legitimized by the UN.

\section{Post-Cold War Nuclear Order and PSI (since 2003)}

While the previous case has highlighted the potential of informal institutions to renegotiate US hegemony, this section illustrates their limits. It is argued that PSI is an exit institution that has failed to tame US hegemony. While PSI addressed the shortterm demands of global nuclear order, it has displayed neither mediative nor transformative effects on the core bargain underlying the nuclear non-proliferation regime. In substantiating such claim, this section will directly draw from the previous case of successful exit and elucidate three criteria that account for variation in the degree of legitimacy enhancement by informal institutions: (i) management of major power relations; (ii) collective hegemony; and (iii) formal legitimation.

Cold War global and nuclear order was closely interrelated. Seen from the US perspective, order involved 'a sophisticated symbiosis of constitutional, balance of power and hegemonic strategies'. ${ }^{81}$ Nuclear order was essentially based on the mutual recognition of US hegemonial and Soviet imperial powers, which helped to stabilize nuclear deterrence and to secure compliance with international obligations within their respective spheres of influence. The end of the Cold War, the demise of the Soviet Union, and the subsequent shift in the global distribution of power has left nuclear order in a state of limbo. While the United States has still aimed at delivering the global public good of nuclear non-proliferation and at providing system maintenance functions, it has failed to attract a critical mass of global followership to build a legitimate post-Cold War nuclear order. Two central questions have arisen. First, who provides and maintains nuclear order in the post-Cold War

81 William Walker, 'Weapons of Mass Destruction and International Order', International Institute for Strategic Studies, Adelphi Paper 370 (Oxford: Oxford University Press, 2004), p. 30. 
world? And secondly, who are the rule-makers and the rule-takers in transforming nuclear order?

\section{Exit to Address the Short-term Demands of Nuclear Order}

The non-proliferation regime is organized around a legal center-piece, the Nuclear Non-Proliferation Treaty (NPT), which opened for signature in 1968 and came into effect in 1970. The Treaty has mostly benefitted the five recognized nuclear weapon states (P-5)—China, France, Russia, United Kingdom, United States—and has failed to deliver on its core bargain: signatory states eschewing nuclear weapons but gaining access to civilian nuclear energy technology in return for the P-5 moving towards nuclear zero. At the same time, the non-proliferation regime has accommodated the three non-signatory, de facto, nuclear weapon countries-India, Israel, and Pakistan, which fostered the perception of an extant unfair and unequal global nuclear order. ${ }^{82}$

The underlying tensions within the non-proliferation regime have become more accentuated in the post-Cold War era primarily for three reasons. First, the end of the Cold War effectively terminated the super power management of global nuclear order. Second, growing energy demands of emerging economies-together with concerns about the volatility of global energy markets and climate change-have led to a nuclear renaissance, especially in Asia. Access to nuclear technology has become essential. And third, the terrorist attacks on the United States in 2001 'dramatically sharpened Americans' sense of vulnerability'. ${ }^{83}$

Rather than aiming for universal constraint, US non-proliferation policies have become more selective, targeting so-called states of proliferation concern while supporting nuclear-armed, though friendly, countries. Especially the bilateral agreement between India and the United States in 2005 and 2006 has been widely criticized, 'overturning more than a quarter of a century of American non-proliferation policy'. ${ }^{84}$ Despite the rhetorical shift of the Obama Administration towards treatybased arrangements and universal constraint, as was visible during the 2010 NPT Review Conference, there is currently no grand nuclear bargain or blueprint for devising a global non-proliferation strategy. Instead, the non-proliferation regime is marked by strategies to meet the short-term demands of WMD order. ${ }^{85}$

The PSI, announced by US President George W. Bush in May 2003, essentially constituted an exit mechanism addressing 'the growing challenge posed by the

82 See Joseph F. Pilat, 'The End of the NPT Regime?', International Affairs, Vol. 83, No. 3 (2007), pp. 469-82.

83 Rosemary Foot and Andrew Walter, China, the United States, and Global Order (Cambridge: Cambridge University Press, 2011), p. 143.

84 Mario E. Carranza, 'From Non-Proliferation to Post-Proliferation: Explaining the US-India Nuclear Deal', Contemporary Security Policy, Vol. 28, No. 3 (2007), p. 464.

85 See Pierre Hassner, 'Who Killed Nuclear Enlightenment?', International Affairs, Vol. 83, No. 3 (2007), pp. 466-7. 
proliferation of weapons of mass destruction (WMD), their delivery systems, and related materials worldwide'. ${ }^{86}$ It sought to fill existing gaps in the current architecture of non-proliferation institutions and mechanisms such as the NPT, the International Atomic Energy Agency (IAEA), the Nuclear Suppliers Group (NSG), and the Missile Technology Control Regime (MTCR).

PSI initially aimed at gathering a maritime coalition of the willing for selective interdiction of vessels with shipments to or from US designated 'rogue' states, that is, Iran, North Korea, Sudan, Syria, and Cuba. ${ }^{87}$ Senior representatives from Australia, France, Germany, Italy, Japan, the Netherlands, Poland, Portugal, Spain, the United Kingdom, and the United States formed the core group that discussed ways and means of implementing the US proposal at subsequent meetings, held in Madrid and Brisbane in June and July 2003, respectively. Two months later, the core group was able to agree on a set of non-legally binding basic principles 'to establish a more coordinated and effective basis through which to impede and stop shipments of WMD, delivery systems, and related materials flowing to and from states and non-state actors of proliferation concern' ${ }^{88}$

The United States subsequently dismantled this core group, responding to concerns that the PSI was two-tiered; it seemed to be run by an inner circle thereby discriminating against others not part of the core group. In fact, PSI is still organized around a two-tiered structure. At the inner circle, there is the Operational Expert Group (OEG), comprising 21 participants led by the US Department of Defense. ${ }^{89}$ OEG engages in information sharing about national legal authorities, develops new operational concepts, and organizes the interdiction exercise program. The outer circle comprises a diverse group of 81 countries that have endorsed PSI and the Statement of Interdiction Principles. The robustness of support is however somewhat unclear. It may range from the formal commitment to and public endorsement of the Statement of Interdiction Principles to the identification of specific national assets that might contribute to PSI goals.

86 The White House, Fact Sheet: Proliferation Security Initiative: Statement of Interdiction Principles, September 4, 2003, http://www.state.gov/t/isn/c27726.htm.

87 See Mark J. Valencia, 'The Proliferation Security Initiative: Making Waves in Asia', International Institute for Security Studies, Adelphi Paper 376 (Abingdon: Routledge, 2005), pp. 25-33.

88 'Proliferation Security Initiative: Statement of Interdiction Principles', Paris, September 4, 2003, http://www.state.gov/t/isn/c27726.htm. As of February 2013, PSI participating countries have conducted a total of 58 Workshops, Joint Interdiction, and Gaming Exercises.

89 The Operational Experts Group currently comprises 21 members, that is, the 11 members of the former core group plus Argentina, Canada, Denmark, Greece, New Zealand, Norway, Republic of Korea, Russia, Singapore, and Turkey. See Mary Beth Nikitin, Proliferation Security Initiative (PSI). Congressional Research Service Report for Congress, June 15, 2012, p. 12. 
In sum, while PSI has provided an exit mechanism that avoids the constraints of IOs, ${ }^{90}$ it has yet failed to successfully address gaps in the legitimacy of the initiative. PSI is built around a narrow and thin version of US-centered multilateralism that essentially limits cooperation to a coalition of willing US followers. Key countries such as Brazil, China, Egypt, India, Indonesia, Malaysia, Pakistan, and South Africa have thus far stayed outside the PSI.

\section{The Legitimacy Deficit of PSI}

PSI illustrates the limits of the coalitions-of-the-willing concept as a means to solve critical 21st Century collective action problems. Coalitions of the willing tend to be ineffective when global power is shifting and the patterns and understandings of global order are deeply contested. Their primary purpose is to facilitate the exercise rather than the renegotiation of hegemony. However, without the direct involvement and (tacit) approval of key stakeholders-e.g. China, India, Brazil, and South Africa-neither can public goods be delivered nor global order be maintained.

According to Kissinger, legitimacy requires 'the acceptance of the framework of the international order by all major powers, at least to the extent that no state is so dissatisfied that ... it expresses its dissatisfaction in a revolutionary foreign policy'. ${ }^{91}$ Consequently, any effort to change or fix the existing nuclear order without the agreement of key stakeholders will be futile. The perception of the PSI as largely US driven, marred by US double standards, and detached from the framework of the UN has led to growing concerns about the legitimacy and the effectiveness of US-led counter-proliferation activities. ${ }^{92}$

There seems to be a striking tendency to conflate concerns about the legality and the legitimacy of WMD order. Without the explicit or tacit agreement of major powers, PSI may be perceived primarily as an US initiative that seeks to create a permissible environment for transforming WMD order solely on US terms. As William Walker has observed:

The idea that international order can be achieved in the modern world without a strong constitutional framework, and without commitment to it by the most powerful states, is a dangerous illusion.... Iraq has shown that such action will tear the fabric of international order if it does not carry wide support and if powerful states are themselves disrespectful of international norms and undertakings. ${ }^{93}$

90 See Michael Byers, 'Policing the High Seas: The Proliferation Security Initiative', American Journal of International Law, Vol. 98, No. 3 (2004), pp. 526-45.

91 Henry A. Kissinger, A World Restored (London: Victor Gollancz, 1977), p. 1.

92 The selectiveness of US non-proliferation policy and the different standards applied vis-àvis India, Israel, and Pakistan have remained a matter of concern. See Nina Srinivasan Rathbun, 'The Role of Legitimacy in Strengthening the Nuclear Nonproliferation Regime', The Nonproliferation Review, Vol. 13, No. 2 (2006), pp. 227-52; Valencia, The Proliferation Security Initiative, p. 69.

93 Walker, Weapons of Mass Destruction and International Order, p. 78. 
The wider debate surrounding UN Security Council Resolution 1540 (2004), which was the first-ever resolution on non-proliferation issues, may illustrate that point. The resolution decided that all states shall

develop and maintain appropriate effective border controls and law enforcement efforts to detect, deter, prevent and combat, including through international cooperation when necessary, the illicit trafficking and brokering in such items (that is, nuclear, chemical, or biological weapons and their means of delivery, J.P.) in accordance with their national legal authorities and legislation and consistent with international law. ${ }^{94}$

The resolution became the first reference point to illustrate the legality of PSIsubsequently followed by Iran and North Korea resolutions 1718 (2006), 1737 (2006), 1747 (2007), 1803 (2008), 1874 (2009), and 1929 (2010). However, the serious concerns expressed by large parts of the UN membership in the debates prior to and after the adoption of Resolution 1540, are rarely mentioned. ${ }^{95}$ While there was broad agreement on the demand to fill a gap in the current non-proliferation architecture, the resolution neither provided-accommodating Chinese objectionsany enforcement authority nor did it explicitly mention interdiction or PSI. ${ }^{96}$ The 118-member strong Non-Aligned Movement (NAM) expressed a widespread uneasiness that Resolution 1540 may create a semi-legal environment for the use of coercive measures, including the use of force, in cases of non-compliance. ${ }^{97}$ In addition, India underlined 'the need for caution on the Security Council being used as a route to short-circuit the process of creating an international consensus'. ${ }^{98}$

In sum, by way of expanding PSI membership and outreach, the United States has sought to build a customary norm of interdiction that is based on selective rather than effective multilateralism. ${ }^{99}$ Following from the above analysis and

94 S/RES/1540, April 28, 2004, operative paragraph 2 (c). However, the resolution does not provide UN member states with the legal authority to board and search vessels suspected of carrying such material. In fact, the UN Convention on the Law of the Sea, adopted in December 1982, asserts the right of freedom of navigation and innocent passage.

95 See the related verbatim records S/PV.4950 and S/PV.4950 (Resumption 1), April 22, 2004; as well as S/PV.4956, April 28, 2004.

96 Although UN Security Council Resolution 1874 (2009) established a framework for cargo inspection of ships coming from or going to North Korea, it did not authorize PSI to assist countries in coordinating their activities. Also, China stressed that 'the issue of cargo inspection is complex and sensitive' and warned against any use of force in implementing the framework. Russia stressed that the inspection framework 'is unprecedented and cannot be interpreted more broadly', S/PV.6141, June 12, 2009, http://www.un.org/ga/search/ view_doc.asp?symbol=S/PV.6141.

97 See the statement of the representative of Malaysia on behalf of the NAM; S/PV.4950 (Resumption 1), April 22, 2004, p. 3.

98 S/PV.4950, p. 23.

99 See Rosemary Foot, 'Selective or Effective Multilateralism? The Bush Administration's Proliferation Security Initiative and China's Response', in Jochen Prantl, ed., Effective 
drawing from the previous case, three criteria can be specified that account for variations in the degree to which informal institutions enhance the legitimacy of the hegemon. All of those are currently absent in the case of PSI:

1. Managing major power relations. Effective security order requires an agreement among major powers on 'the rules of the game'. The end of the Cold War effectively terminated the super power management of global nuclear order. A new set of major power bargains is needed to lay the foundation of the post-Cold War nuclear order.

2. Collective hegemony. Transforming US hegemony into collective hegemony helps to bind key stakeholders into a single cooperative framework, which establishes checks and balances within a concert of powers. As it stands, the PSI is a coalition of the willing that excludes key stakeholders and leaves US (single) hegemony largely intact.

3. Formal legitimation. Achieving formal approval by IOs such as the UN helps to mobilize a critical mass of international followership to legitimize collective action outcomes.

\section{G-20 and the Global Financial Crisis of 2008}

The meltdown of financial markets in 2008 epitomized, in Joseph Stiglitz' words, the ideological crisis of Western capitalism. ${ }^{100}$ With banks collapsing in the United Kingdom (2007) and the United States (2008), followed by the global financial crisis and the sovereign debt crisis in Europe, the meltdown called into question the socalled Washington Consensus that market liberalization and deregulation of financial markets and capital flows are the universal key to economic growth and increasing human welfare. ${ }^{101}$ It also called into question the ability of the United States to deliver what is widely considered a key hegemonic imperative, that is, the provision of financial public goods. In a nutshell, the global financial crisis of 2008 raised questions 'about the longer-term position of the Anglo-American and European global order that rose to dominance in the middle of the nineteenth century and around which so many conceptions and practices of power-political order, international legal construction and global economic governance have since been constructed'. ${ }^{102}$ The principles, preferences, and ideas underlying US hegemony have become contested.

Multilateralism: through the Looking Glass of East Asia (Basingstoke: Palgrave Macmillan, 2013), pp. 215-31.

100 Joseph E. Stiglitz, 'The Ideological Crisis of Western Capitalism', Project Syndicate, July 6, 2011.

101 See Foot and Walter, China, the United States, and Global Order, p. 106.

102 Andrew Hurrell, 'Effective Multilateralism and Global Order', in Prantl, ed., Effective Multilateralism, p. 22. 


\section{The Predicament of Western Liberal Economic and Financial Institutions}

The crisis illustrated the impotence of Western liberal economic and financial institutions-particularly the IMF and the G-7/8 - to act as effective problemsolvers. Yet, their institutional decline in fact preceded the 2008 financial crisis. Two factors had generated the decline of the G-8. ${ }^{103}$ First, G- 8 members were unwilling to practise what they preach, which became apparent especially after the financial crises in Mexico (1994), Argentina (1995; 2000-2001), Indonesia, Korea, and Thailand (1997-1998), Russia (1998), Brazil (1998-2002), Turkey (1999-2002), and Uruguay (2002). The utility of the institution in identifying policy shortcomings of its own members had severely eroded. Second, the G-8 was widely considered a hegemonic club, which largely excluded emerging economies such as Brazil, China, and India. The lack of G-8 representativeness had further contributed to the steep decline of legitimacy for the institution.

At the same time, the IMF's decline had been triggered by a combination of formal institutional constraints and poor policy recommendations. Institutionally, the IMF was criticized for a voting system that heavily favoured Western powers, and particularly the United States. ${ }^{104}$ Furthermore, the deeply inappropriate policy reforms recommended by the IMF to countries affected by the 1997-1998 East Asian financial crisis had exacerbated its loss of legitimacy. IMF clients such as Argentina, Brazil, Russia, and South Korea decided to make alternative arrangements and to apply for loans elsewhere.

In sum, even prior to the meltdown of financial markets in 2008 Western liberal economic and financial institutions faced a crisis of legitimacy and needed overhauling in order to stay relevant as problem-solvers. The global financial crisis constituted therefore the trigger rather than the root cause for the failure of global institutions.

\section{G-20 Ascendancy: Voice for Emerging Economies}

The above mentioned series of financial crises in Latin America, East Asia and elsewhere between 1994 and 2002 made abundantly clear that key emerging economies were only poorly integrated in the management of global economy and finance, with very limited voice opportunities. Collective action in response to the crises was still based on a de-facto centralization of US power and the institutional support

103 See, for example, the report and recommendations of the 'Shadow G-8' for the Evian Summit. Shadow G-8, 'Pour une nouvelle légitimité du G-8', Politique étrangère, Vol. 68, No. 2 (2003), pp. 245-58.

104 See Ngaire Woods, 'Making the IMF and the World Bank More Accountable', International Affairs, Vol. 77, No. 1 (2001), pp. 83-100; Ngaire Woods and Domenico Lombardi, 'Uneven Patterns of Governance: How Developing Countries are Represented in the IMF', Review of International Political Economy, Vol. 13, No. 3 (2006), pp. 480-515; Rodrigo de Rato, 'The IMF View on IMF Reform', in Edwin M. Truman, ed., Reforming the IMF for the $21^{\text {st }}$ Century (Washington, DC: Peterson Institute for International Economics, 2006), pp. 127-31. 
structure of the Western liberal order. The financial crises triggered a number of adjustments to strengthen the inclusiveness and representativeness of the G-x financial coordination process. Especially then-Canadian Finance Minister, Paul Martin, and then-US Treasury Secretary, Lawrence Summers, pushed for the involvement of key regional powers-Argentina, Australia, Brazil, China, India, Indonesia, Mexico, Saudi Arabia, South Africa, South Korea, and Turkey-plus the European Union, which eventually led to the creation of the Group of Twenty Finance Ministers and Central Bank Governors (G-20) in December 1999.

The G-20 sought to facilitate cooperation among systemically important developed and emerging economies in achieving financial stability of an increasingly interdependent global economy. ${ }^{105}$ At the heads of government level, since 2005, the G-8 had established regular meetings with Brazil, China, India, Mexico, and South Africa. ${ }^{106}$ However, all those adjustments were made on Western terms and essentially constituted an extension of the Anglo-American and European global institutional architecture. This approach effectively changed in 2008 when the G-20 at the leaders' level was convened to mitigate the fallout of the crisis. The new leadership forum constituted in the first instance a voice mechanism for emerging economies, reflecting the need for a more representative steering group in addressing urgent issues of global governance.

\section{Mediating US Hegemony in Global Financial Governance}

After the collapse of Lehman Brothers, the meltdown of global financial markets led to the renegotiation and rescue rather than resistance and replacement of the U.Sled global economic order. In this context, the primary logic of the G-20 Leaders forum has been mediative. The US initiative to call and host a summit of G-20 Leaders in Washington D.C. in November 2008 highlighted three crucial points. First, the United States was no longer in the position to deliver on the hegemonic imperative of providing financial goods without the support of emerging economies. ${ }^{107}$ Second, the financial crisis could not be solved through 'traditional' modes of multilateralism that were largely based on the centralization of US power. And third, the G-7/8 was no longer considered the primary steering committee for global financial governance through which US hegemonic leadership could be exercised.

The subsequent G-20 Leaders summits renegotiated the terms and conditions of US hegemony: advanced economies support greater voice for emerging countries in

105 For a historical account of the G-x process, see Peter Hajnal, The G8 System and the G20: Evolution, Role and Documentation (London: Ashgate, 2007).

106 Russia joined the G-7 in 1997. The G-8+5 meetings were formalized at the 2007 Heiligendamm Summit in Germany.

107 See Alan S. Alexandroff and John Kirton, 'The "Great Recession" and the Emergence of the G-20 Leaders' Summit', in Alan S. Alexandroff and Andrew Cooper, eds., Rising states, Rising institutions: Challenges for Global Governance (Cambridge: Cambridge University Press, 2010), pp. 177-95. 
global financial governance while the latter help sharing the burden in contributing to global capital liquidity. The core bargain underlying global financial order however would remain unchanged. On resources, the 2009 G-20 London Summit raised $\$ 750$ billion in new funds available through the IMF and increased the capital endowments of the multilateral development banks for global development and stimulus. Brazil, China, India, and Russia (the 'BRIC' countries) subsequently became key contributors to the IMF's emergency loan pool-the New Arrangements to Borrow or NAB - and now provide $15.5 \%$ of the NAB resources. They are 4 of the Fund's top 10 shareholders. ${ }^{108}$ On institutional reform, the G-20 Leaders negotiated a shift of $6 \%$ of quota shares to emerging and developing countries. Under the new agreement—pending implementation — the BRIC will be able to collectively veto the activation of IMF credit lines. ${ }^{109}$ However, these changes will come primarily at the expense of Britain, France, and Saudi Arabia rather than the United States. The veto power of the United States has remained intact. The London Summit also decided to expand the membership and enhance the mandate of the G7 Financial Stability Forum, to include G-20 countries in early warning of macroeconomic and financial risks. ${ }^{110}$ On rules and regulations, the Basel Committee on Banking Supervision (BCBS) providing voluntary international standards and best practices for financial regulations and supervision, was essentially kept intact, despite the widespread criticism that the Basel framework had done little to prevent the 2008 crisis. $^{111}$

In a nutshell, emerging powers helped in rescuing rather than replacing the existing global financial order, given the lack of alternatives to US hegemony. Looked at from the perspective of China-with $46 \%$ the largest holder of official US debt in $2008^{112}$ - its policies were driven by the vital short-term interest of protecting itself from the worst repercussions of the financial meltdown, and in particular of the 'dollar standard'. ${ }^{113}$ Chinese overdependence on the US dollar as its key reserve currency made any revolutionary approach to replace the existing economic order

108 See www.imf.org/external/np/exr/facts/gabnab.htm.

109 Ngaire Woods, 'Global Governance after the Financial Crisis: A New Multilateralism or the Last Gasp of the Great Powers?', Global Policy, Vol. 1, No. 1 (2010), pp. 51-63.

110 The Financial Stability Forum was transformed into a Financial Stability Board. See Ignazio Angeloni and Jean Pisani-Ferry, The G20: Characters in Search of an Author, Bruegel Working Paper 2012/04.

111 See Foot and Walter, China, the United States, and Global Order, pp. 229-73. On the role of the BCBS in global economic governance, see Ethan B. Kapstein, 'Resolving the Regulator's Dilemma: International Coordination of Banking Regulations', International Organization, Vol. 43, No. 2 (1989), pp. 323-47.

112 See Daniel W. Drezner, 'Bad Debts: Assessing China's Financial Influence in Great Power Politics', International Security, Vol. 34, No. 2 (2009), p. 13.

113 Quoted in Peter Ferdinand and Jue Wang, 'China and the IMF: From Mimicry towards Pragmatic Institutional Pluralism', International Affairs, Vol. 89, No. 4 (2013), p. 910. 
extremely unlikely. ${ }^{114}$ It would have carried the risk of significantly reducing the value of Chinese dollar assets. Interestingly, it was China that had pushed hard inside and outside the G-20 to maintain the BCBS, as it needed the framework as a lever for reforming its major banks. ${ }^{115}$

Yet, there are clear limits to the narrative of emerging powers being co-opted into the architecture of Western liberal financial institutions and of lacking alternatives to US hegemony. Their compliance ultimately depends on three factors: first, the continued ability of the US hegemon to provide global financial public goods through provision of the world's reserve currency; second, the continued willingness of emerging powers to share the burden of providing global capital liquidity through the IMF; and third, the commitment of the United States and Europe to fulfil their part of the renegotiated contract by granting emerging powers more voice in global financial governance. China's long-term interest in 'escaping from domination by the US dollar' ${ }^{116}$ exposes the serious limits of the 'unlimited-co-optation-narrative'.

There are already signs of 'moderately revisionist' approaches to establish alternative mechanisms and norms to challenge Western liberal institutions. ${ }^{117}$ China has been a driver to create a BRICS development bank, including a $\$ 100$ billion reserve arrangement, to help address future financial crises in BRICS economies. Despite their diverse composition of democratic and non-democratic countries, BRICS countries have managed to address their differences and to find a common denominator to challenge liberal order, if necessary. BRICS development bank and reserve arrangement constitute exit signposts operating outside the liberal institutional architecture. They may be transformed into full institutional alternatives if the following thresholds are being crossed: (i) the incumbent hegemon is no longer able to deliver public goods; (ii) voice opportunities within Western liberal institutions will not fully materialize; and (iii) exit will be more conducive to the long-term strategic goals of emerging powers, especially if there is a critical mass of followers to support these goals. While none of the thresholds has been crossed so far, there are signs of frictions. BRICS countries have been concerned about the long delay in implementing G-20 decisions to provide emerging economies with greater voice in the IMF, especially in light of US Congress' refusal in early 2014 to ratify IMF reform. ${ }^{118}$ If the perception prevails that the United States is in breach of contract, BRICS may want to pursue exit by fully developing an alternative to the existing global financial order. ${ }^{119}$

114 See Goh, The Struggle for Order, pp. 147-56.

115 See Foot and Walter, China, the United States, and Global Order, p. 273.

116 Ferdinand and Wang, 'China and the IMF', p. 910.

117 David Shambaugh, China Goes Global: The Partial Power (New York: Oxford University Press, 2013), p. 125.

118 See Robin Harding, 'US Fails to Approve IMF Reforms', Financial Times, January 14, 2014.

119 In addition, China's recent decision to establish a new Asian Infrastructure Investment Bank is yet another example of exit signposts that may challenge the established global and regional institutions such as the World Bank and the Asian Development Bank. 
In sum, the G-20 Leaders emerged as a voice institution-at the initiative of the United States-that co-opted emerging powers into the framework of Western liberal institutions to address the immediate concerns of the 2008 global financial crisis. The logic of the G-20 has been mediative. It provides political space for the contestation and renegotiation (but not replacement) of US hegemony in global financial governance. At the same time, BRICS countries have developed exit signposts of governance that can be fully activated if the United States-and with it the G-20 and the IMF-fail to deliver.

\section{Conclusions}

The novelty of the analytical framework offered in this article rests on three problems of mainstream international relations theory. First, existing neoliberal accounts of the constitutional bargain between the United States and liberal institutions are too static, because they tend to neglect crucial aspects that reside in the negotiation of and contestation over US hegemony. Second, mainstream international relations theory tends to obscure variations in the expression of hegemony across regions. And third, standards accounts tend to ignore the boundaries of the hegemonic contract, which can ultimately be revoked.

Investigating the relationship between US hegemony, informal institutions, and IOs helps to expose the changing character of the constitutional bargain, which constitutes part and parcel of Western liberal order in transition. The substantial challenges for liberal institutions to adapt to major shifts in the global distribution of power and to act as effective problem-solvers has led to growing recourse to informal mechanisms for collective action that operate in and around the liberal institutional architecture. Informal institutions provide a vital space to renegotiate the terms and conditions of US hegemony underlying Western liberal order. They display two broad logics. First, voice institutions can be mediative by restraining the United States' ability to waive the rules in order to rule the waves, yet without the hard constraints of formal IOs. The second logic is transformative. Dissatisfied powers may use exit institutions to remedy grievances through direct negotiations with the hegemon in a small-n setting that may lead to a new bargain underlying global or regional order. In consequence, the risk of hegemonic instability may be reduced, as those mechanisms establish regular procedures of interaction and help to address concerns about the legitimacy of US foreign policy. As the Contact Group on former Yugoslavia has illustrated, these regular procedures may transform US hegemony into collective hegemony by establishing checks and balances within a concert of powers.

However, informal institutions are not the convenient support structure for the renegotiation of Western liberal order on exclusive US terms. The highly contested nature of US hegemony has deepened in the post-Cold War order. There are clear limits in sustaining US hegemony. While the Contact Group on former Yugoslavia in the early to mid-1990s demonstrated the potential of informal mechanisms to 
accommodate and complement the workings of Western liberal institutions, the PSI-created in 2003-has pointed to the limits of an imagined informal support structure. Especially after the global financial crisis of 2008, the shifts in the distribution of power have started to take hold. Providing public goods and keeping a critical mass of US followers has become harder in light of the growing contestation of liberal principles, preferences, ideas, and values. In global financial governance, the US imperative of providing public goods is contingent upon the willingness of emerging powers to share the burden of generating sufficient global capital liquidity and to buy into the underlying principles of liberal financial order. At the same time, BRICS countries have started developing exit signposts such as the BRICS development bank, which can be transformed into real institutional alternatives, if the United States and Europe will not fulfil their part of the contract. The BRICS provide an example for the potentially competitive and substitutive nature of informal institutions. BRICS countries may eventually develop new patterns and understandings of global governance that ultimately replace Western liberal order. The social contract between hegemonic leader and followers can be revoked.

\section{Acknowledgement}

The author is very grateful to Rosemary Foot, Evelyn Goh, and Andrew Hurrell for their thoughtful advice, criticisms, and ideas on earlier drafts of this article. Comments by the three anonymous referees are greatly appreciated. 